\title{
Publicidade, estudos culturais e seus paradigmas em decoding advertisements, de Judith Williamson
}

\author{
Advertising, cultural studies and your paradigms in decoding advertisements, by \\ Judith Williamson
}

\section{Publicidad, estudiosculturales y sus paradigmas endecodingadvertisements de Judith Williamson}

Rodolfo Rorato Londero ${ }^{1}$

http://dx.doi.org/10.5216/31599

\section{Resumo}

O objetivo deste artigo é revisar DecodingAdvertisements, de Judith Williamson, obra de referência dos Estudos Culturais sobre publicidade. O artigo descreve como os dois paradigmas dos Estudos Culturais ("culturalismo" e estruturalismo) estão relacionados na obra de Williamson, indicando o paradigma estruturalista como o mais influente, principalmente devido à predileção da autora pela semiologia barthesiana, pelo conceito althusseriano de interpelação e pela noção lacaniana de estágio do espelho. A respeito do paradigma culturalista, ligado ao pensamento marxista, nota-se que Williamson comete alguns equívocos, como se demonstra recorrendo aos seus críticos. A principal crítica a DecodingAdvertisements é explicar a publicidade somente como estrutura, sem abordá-la enquanto processo.

Palavras-chave: Publicidade. Estudos Culturais. Estruturalismo.

\begin{abstract}
The purpose of this paper is to review Decoding Advertisements, by Judith Williamson, a major work of Cultural Studies about advertising. The paper describes how the two paradigms of Cultural Studies ("culturalism" and structuralism) are associated in the Williamson's work, indicating the structuralist paradigm as the most influential, as shown in the author's predilection for Barthesian semiology, Althusserian concept of interpellation and Lacanian notion of mirror stage. Regarding the culturalist paradigm, linked to Marxist thought, we note that Williamson concedes some misconceptions, as demonstrated using its critics. The main criticism to Decoding Advertisements is to explain advertising only as structure, without addressing it as process.
\end{abstract}

Keywords:Advertising. Cultural Studies. Structuralism.

\section{Resumen}

El propósito de este artículo es revisar DecodingAdvertisements de Judith Williamson, obra de referencia de los Estudios Culturales en la publicidad. El artículo describe cómo los dos paradigmas de los Estudios Culturales ("culturalismo" y estructuralismo) se relacionan en el libro de Williamson, que indica el paradigma estructuralista como el más influyente debido a la preferencia del autor por la semiología de Barthes, por el concepto de interpelación de Althussery por la noción del estadio del espejo de Lacan. En relación con el paradigma culturalista, vinculado al pensamiento marxista, observamos que Williamson comete algunos errores, como lo demuestra sus críticos. La principal crítica a DecodingAdvertisements es explicar la publicidad sólo como estructura sin abordarla como proceso.

Palabras clave:Publicidad. EstudiosCulturales. Estructuralismo.

\footnotetext{
${ }^{1}$ Doutor em Estudos Literários pela Universidade Federal de Santa Maria (UFSM). Professor do Departamento de Comunicação da Universidade Estadual de Londrina (UEL). Brasil, Paraná, Londrina. E-mail: rodolfolondero@bol.com.br
}

Comun. \& Inf., Goiânia, GO, v. 18, n. 1, p. 37-54, jan./jun. 2015 


\section{INTRODUÇÃO}

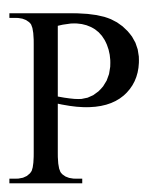

or que retornar a uma obra considerada "datada", como se refere Wells (2004) a respeito de DecodingAdvertisements: IdeologyandMeaning in Advertising(1978)? Caso se procure traçar um panorama histórico das teorias da publicidade, o retorno à obra de Judith Williamson é plenamente justificado, pois trata-se da principal referência dos Estudos Culturais sobre publicidade, desconsiderando a breve passagem, porém brilhante, de Raymond Williams em "Publicidade: o sistema mágico" (1960). Entretanto, ao contrário de Williams, Williamson apoiou parte considerável de sua análise da publicidade naquilo que Hall (2003a) identificou como paradigma estruturalista dos Estudos Culturais, adotando os princípios da semiologia, mas também conceitos oriundos de Althusser, Lacan, Foucault e Lévi-Strauss. Esta identificação se evidencia quando acompanhamos a trajetória de sucesso da obra. Segundo Wells, DecodingAdvertisements "tornou-se proeminente muito rapidamente e, em 1982, estava em sua quarta impressão"2 (WELLS, 2004, p.165). Na verdade, no mesmo ano de 1982, ou seja, quarto anos após sua primeira publicação, DecodingAdvertisements já recebia destaque em Advertising as Communication (1982), de Gillian Dyer, conhecida obra introdutória aos estudos da publicidade lançada pela série Studies in Communication, sob coordenação geral de John Fiske. Dyer cita Williamson diversas vezes ao longo do capítulo "Semiótica e Ideologia", além de apresentar o seguinte comentário em sua bibliografia anotada: "Uma análise da publicidade interessante, mas às vezes complexa, utilizando a semiótica como base para uma crítica ideológica e psicanalítica" (DYER, 1982, p.225). Quatro anos depois, em Social Communication in Advertising (1986), o estudo de Williamson é citado como "uma das melhores análises semiológicas" (LEISS; KLINE; JHALLY, 1986, p.153), consagrando assim sua rápida ascensão nos círculos dos Estudos Culturais.

Ainda que a trajetória de DecodingAdvertisements seja suficiente para justificar um artigo de revisão, nosso motivo reside em seu último suspiro de crítica ideológica antes da virada (derrocada?) política e epistemológica dos Estudos Culturais ocorrida nos anos 1980 e marcada pelo "retorno ao prazer ordinário [que] se fazia explicitamente em nome da necessária ruptura com a pesada tradição de teorias negativas inspiradas pela Escola de Frankfurt e pela corrente estruturalista" (MATTELLART; NEVEU, 2004, p.117). Este retorno, como também o momento pós-estruturalista, permitiu a desideologização da semiologia, acompanhada de sua transformação em instrumento de criação publicitária: se

\footnotetext{
${ }^{2}$ Todas as citações de obras em língua estrangeira foram livremente traduzidas por nós.
} 
Santaella e Nöth (2010) se referem aos aspectos crítico-ideológicos como o passado da semiótica da publicidade, então é porque suas Estratégias Semióticas da Publicidade (2010) não seriam possíveis de outra maneira. $\mathrm{Na}$ verdade, mais de duas décadas após a primeira publicação de DecodingAdvertisements, Williamson reconhece à contragosto que "ideologia é uma palavra muito fora de moda: no clima intelectual de hoje, ela soa como um dinossauro stalinista" (WILLIAMSON, 2002, p.8). Contudo, essa inversão de propósitos - da análise crítica ao instrumento de criação - parece inerente a qualquer tentativa de entender como a publicidade funciona, sendo curioso notar que

havia rumores de que, tal quais publicações como o livro The HiddenPersuaders, de Vance Packard, DecodingAdvertisements rapidamente se juntou aos textos clássicos nas prateleiras das principais agências de design. Entender como os anúncios funcionam é útil tanto para o publicitário quanto para o semiologista, apesar de seus objetivos subjacentes diferirem radicalmente (WELLS, 2004, p.166).

A própria Williamson se mostrou surpresa ao perceber que, quatro anos depois da publicação de DecodingAdvertisements, a publicidade se tornou mais consciente do uso da semiologia: "muitas das práticas formais de publicidade que senti que estava brincando como implícitas aos anúncios, agora são explícitas" (WILLIAMSON, 1992, p.7; grifo da autora). É igualmente surpreendente também perceber o caminho inverso, como quando semiologistas conhecidos tornam-se consultores de agências de publicidade ${ }^{3}$ (Jean Marie-Floch, Eliseo Verón, etc.). Em ambos os casos, estamos distantes do objetivo de uma teoria da publicidade, pelo menos como imaginada por Williamson: se a publicidade é uma forma pública que nos influencia privadamente, então a teoria deve quebrar o isolamento da luta individual (WILLIAMSON, 2002, p.10).

Buscando revisar a obra de Williamson, este artigo se propõe a descrever como os dois paradigmas dos Estudos Culturais estão relacionados em DecodingAdvertisements, abordando primeiramente o paradigma estruturalista. A respeito do paradigma culturalista, ligado ao pensamento marxista, percebe-se que Williamson cometeu algumas falhas, como se pretende demonstrar recorrendo aos seus comentaristas. Contudo, nas considerações finais do artigo, nota-se que as falhas de Williamson não comprometem a ambição crítica de sua obra.

\footnotetext{
${ }^{3}$ A respeito da prática publicitária, Williams já alertava em 1960: "É monstruoso que os avanços humanos na psicologia, na sociologia e nas comunicações possam ser usados ou pensados como técnicas poderosas contra as pessoas, do mesmo modo como é baixo tentar reduzir a faculdade da escolha humana à 'resistência às vendas'" (WILLIAMS, 2001a, p.259). Se isto continua a acontecer hoje, então é porque criou-se algum tipo de bloqueio ético entre pesquisadores e publicitários, oriundo provavelmente da descrença inconsciente ou do cinismo consciente: que mal pode causar a semiologia aplicada a anúncios de detergente?
}

Comun. \& Inf., Goiânia, GO, v. 18, n. 1, p. 37-54, jan./jun. 2015 


\section{O PARADIGMA ESTRUTURALISTA}

A famosa frase de Marx em $O 18$ Brumário resume a relação conflituosa entre o paradigma culturalista e o estruturalista no interior dos Estudos Culturais: "Os homens fazem sua própria história, mas não a fazem como querem; não a fazem sob circunstâncias de sua escolha e sim sob aquelas com que se defrontam diretamente, legadas e transmitidas do passado" (MARX, 2008, p.19). Os homens fazem sua própria história... é a divisa do paradigma culturalista, definindo a cultura "como a atividade através da qual homens e mulheres fazem a história" (HALL, 2003a, p.142). Por outro lado, ...não a fazem como querem é o lema do paradigma estruturalista, lembrando que a cultura é formada por "categorias e quadros de referência linguísticos e de pensamento através dos quais as diferentes sociedades classificam suas condições de existência" (HALL, 2003a, p.146). Hall demonstra o impasse entre "culturalismo" e estruturalismo através do conceito de experiência:

Enquanto no 'culturalismo' a experiência era o solo - o terreno do 'vivido' em que interagiam a condição e a consciência, o estruturalismo insistia que a 'experiência', por definição, não poderia ser o fundamento de coisa alguma, pois só se podia 'viver' e experimentar as próprias condições dentro e através de categorias, classificações e quadros de referência da cultura. Essas categorias, contudo, não surgiram a partir da experiência ou nela: antes, a experiência era um 'efeito' dessas categorias (HALL, 2003a, p.147; grifo do autor).

Os homens experimentam as condições ou são experimentados por elas? Eles fazem a história ou a história os faz? Eles agem livremente ou sob condições determinadas? Sem querer abordar as conclusões de Hall a respeito das relações entre os dois paradigmas, é importante frisar o modo desigual como Williamson os sintetiza em sua obra, favorecendo o estruturalismo em detrimento do "culturalismo". Quando define a função da publicidade como, além de vender, criar estruturas de significados, Williamson se interessa não tanto em como as pessoas experimentam a publicidade, mas em como a publicidade cria significados que estruturam a experiência das pessoas: "Os anúncios estão nos vendendo algo mais além de bens de consumo: ao nos fornecer uma estrutura em que nós e esses bens são intercambiáveis, eles estão nos vendendo a nós mesmos" (WILLIAMSON, 2002, p.13).

DecodingAdvertisements encontra-se naquele momento dos Estudos Culturais definido por Hall como "virada linguística", preocupado em pensar a textualidade como local de poder (HALL, 2003b, p.211). Sendo assim, para Williamson, "os marxistas - e qualquer um que queria mudar radicalmente nosso mundo - não pode se dispor a rejeitar algumas das 
teorias estruturalista-semióticas básicas" (WILLIAMSON, 1992, p.6). Vejamos a partir de agora como Williamson se utiliza dessas teorias para compreender a publicidade.

Apoiada na famosa divisão saussuriana entre langue e parole, ou seja, entre as regras estruturais e os usos individuais da língua, Williamson pretende demonstrar como a estrutura da publicidade funciona, sem desconsiderar que, ao contrário da língua, "os componentes dos anúncios são variáveis e não necessariamente fazem parte de uma única linguagem ou discurso social" (WILLIAMSON, 2002, p.12; grifo da autora). Seu ponto de partida é a diferenciação, conceito central da linguística saussuriana que justifica a arbitrariedade do signo: "gato" é "gato" porque não é "rato" ou "mato". Por outro lado, a publicidade enfrenta um problema inverso, pois "há uma diferença muito pequena entre marcas de produtos dentro de qualquer categoria, como detergentes, margarinas, papéis-toalha, etc."4 (WILLIAMSON, 2002, p.24). Sendo assim, a publicidade precisa fabricar as diferenças dos produtos a partir de diferenças já estabelecidas: "Os anúncios se apropriam das relações formais de sistemas de diferenças preexistentes. Eles usam distinções existentes nas mitologias sociais para criar distinções entre produtos" (WILLIAMSON, 2002, p.27). Esses sistemas de diferenças preexistentes formam os sistemas de referência da publicidade (WILLIAMSON, 2002, p.26). Na verdade, para Williamson, a publicidade transfere as diferenças originárias dos sistemas de referênciapara os produtos, utilizando-as como moeda de troca (currency): "Currency é algo que representa um valor e que em seu intercâmbio com outras coisas, atribui a elas o seu 'valor' também" (WILLIAMSON, 2002, p.20). Esta transferência "monetária" concretiza-se na publicidade enquanto uma correlação objetiva entre os sistemas de referência e o sistema do produto, apagando assim o próprio momento de transferência (WILLIAMSON, 2002, p.29). Por exemplo, os anúncios do refrigerante Guaraná Antarctica frequentemente se apoiam na suposta origem natural do produto para o diferenciar da suposta origem artificial da concorrência. A origem natural não apenas diferencia o produto, mas atribui seu valor a ele. Ou melhor, ao atribuir o valor de natural ao produto, os anúncios estabelecem a diferença. Isto é possível não apenas devido à diferença preexistente entre natural e artificial (sistema de referência antropológico), mas principalmente devido à valoração positiva do primeiro em relação ao segundo, pelo menos desde o romantismo (sistema de referência cultural). Entretanto, realizada a transferência, Guaraná Antarctica torna-se sinônimo de natural e viceversa. Adaptando o esquema de Williamson para nosso exemplo, podemos representar a correlação objetiva do seguinte modo:

4 A publicidade como diferenciação de produtos é um tópico frequentemente explorado pelos autores estruturalistas, como se percebe em Baudrillard (1973), Moles (1974), Péninou (1976), etc. 


$\begin{array}{ccc}\text { Natural } & \neq & \text { Artificial } \\ = & =\end{array}$

\section{Guaraná Antarctica $\neq$ Concorrência}

Portanto, para Williamson, os anúncios formam "uma meta-estrutura onde o sentido não é apenas 'decodificado' dentro de uma estrutura, mas transferido para criar outra. Dois sistemas de sentido estão sempre envolvidos: o 'sistema de referência' e o sistema do produto" (WILLIAMSON, 2002, p.43; grifo da autora).

Williamson (2002, p.99-101) emprega a noção de meta-estrutura da publicidade a partir dos conceitos de denotação e conotação desenvolvidos por Barthes em Elementos de Semiologia (1964). Na verdade, o próprio Barthes já havia empregado esses conceitos para explicar a publicidade, observando nos anúncios duas mensagens: a mensagem de denotação, cujo significante e significado se encontram "em relação ao real que toda a linguagem supostamente 'traduz'" (BARTHES, 1987, p. 166); e a mensagem de conotação, cujo "significado é único e é sempre o mesmo, em todas as mensagens publicitárias" ("a excelência do produto anunciado") e cujo significante é "formado pela primeira mensagem na sua totalidade, pelo que podemos dizer que a segunda mensagem conota a primeira (que, como vimos, era de simples denotação)" (BARTHES, 1987, p. 166-167; grifos do autor). No entender de Williamson, a "excelência do produto anunciado", aquilo que o torna diferente, decorre dos valores conotados pelos sistemas de referência, termo que a autora emprega como sinônimo de "signo denotado" (WILLIAMSON, 2002, p.99).

A ideologia da publicidade reside em seu processo incontrolável de conotação, englobando sistemas dentro de sistemas infinitamente (o creme hidratante que deixa minha pele suave que me torna bonita que me garante admiração dos homens que...): para Williamson, "os anúncios (ideologias) podem incorporar qualquer coisa, mesmo reabsorver a crítica de si mesmos, porque eles se referem a isto desprovidos de conteúdo" (WILLIAMSON, 2002, p.167). Acompanhando o pensamento de Williamson, Vestergaard e Schroder observam uma capacidade de recuperação da publicidade, inclusive de atitudes hostis: como exemplo, os autores citam a recuperação do movimento feminista por um anúncio de perfume intitulado "Por que uma mulher não pode ser como uma mulher?"

Comun. \& Inf., Goiânia, GO, v. 18, n. 1, p. 37-54, jan./jun. 2015 
(VESTERGAARD; SCHRODER, 1988, p.183-185). Esta capacidade de recuperação explica o próprio funcionamento da publicidade: "os anúncios devem funcionar não no nível evidente de 'o que é dito' ('Persil lava mais branco', etc.) - porque isto não é acreditado -, mas no nível do significante" (WILLIAMSON, 2002, p.174-175; grifo da autora). O significado dos anúncios é deliberadamente desacreditado, promovendo seu esvaziamento e, consequentemente, libertando o significante em direção ao intercâmbio total. Baudrillard chama isto de nível zero da publicidade: "a forma publicitária é aquela em que todos os conteúdos singulares se anulam no próprio momento em que podem transcrever-se uns nos outros" (BAUDRILLARD, 1991, p. 113). O anúncio citado por Vestergaard e Schroder mostra este nível zero, pois nele é possível ser feminista e feminina, tomar decisões e deixar que os homens pensem que eles tomaram (VESTERGAARD; SCHRODER, 1988, p.183).

Podemos comparar a publicidade, como definida por Williamson, às mitologias, como definidas por Barthes: "O mito não se define pelo objeto da sua mensagem, mas pela maneira como a profere" (BARTHES, 1980, p.131). Como a publicidade, qualquer objeto é tema de mito, desde que seja proferido como metalinguagem, como uma linguagem que fala sobre outra linguagem, a linguagem-objeto. Deste modo, Barthes compreende o mito enquanto fala roubada e restituída, sendo que "a fala que se restitui não é exatamente a mesma que foi roubada" (BARTHES, 1980, p. 147), pois o mito rouba a fala da linguagem-objeto, restituindo em seu lugar uma nova fala. Contudo, para Williamson, a publicidade não rouba nada, pois

o produto, que inicialmente não tem 'sentido', precisa receber valor de uma pessoa ou objeto que já tem valor para nós, i. e., que já tem sentido. Portanto, neste estágio, algo do produto torna-se o significado e o objeto ou pessoa correlacionado é o significante (WILLIAMSON, 2002, p.31).

Em nenhum momento há uma fala da linguagem-objeto para se roubar: o produto é tomado desde o início como carente de sentido, como vazio a se preencher através de outro valor já conhecido. Este é o primeiro estágio do processo de transferência realizado pela publicidade. No segundo estágio, o produto torna-se significante: “O próximo estágio, depois de um produto ter o sentido transferido para ele de outro objeto, é quando o próprio produto começa a significar. Ele pode começar como reflexo de algo exterior, mas em breve virá para representá-lo" (WILLIAMSON, 2002, p.35). Primeiro o significante "planta do guaraná" e o significado "Guaraná Antarctica", depois o significante "Guaraná Antarctica" e o significado "todo mundo tem sede de natureza" (slogan de 1977), "a pedida natural" (2003), etc. No terceiro estágio, o produto-signo do anúncio torna-se um referente potencial: 
Um produto pode representar uma qualidade abstrata ou sentimento para depois gerar ou ser aquele sentimento; ele pode tornar-se não apenas "signo", mas um verdadeiro referente daquele signo. Uma coisa é um produto significar felicidade, outra é ele ser ou criar felicidade. Um produto é sempre um signo dentro da publicidade: enquanto você não estiver em posse dele ou o consumindo, ele permanece como um signo e um referente potencial; mas o ato de comprar/consumir é o que liberta o referente emocional em si (WILLIAMSON, 2002, p.36; grifos da autora).

É por isso que "nos anúncios os produtos estão sempre não-consumidos, aguardando" (WILLIAMSON, 2002, p.161), pois eles devem se apresentar como futuro prometido, como promessa a se cumprir caso se realize o que está para acontecer nos anúncios. Por exemplo, nos anúncios de marcas de cerveja, o clima descontraído envolvendo piadas, curtições e comemorações torna-se possível quando reunimos os amigos para tomar uma Skoll ou uma Brahma. Neste caso, "o produto não apenas representa uma experiência emocional, mas torna-se aquela experiência e produz ela: seus papéis como signo e referente entram em colapso juntos" (WILLIAMSON, 2002, p.38; grifos da autora). O colapso entre signo e referente é o mesmo entre "culturalismo" e estruturalismo. É a experiência de clima descontraído que embasa (fornece "base") a "superestrutura" dos anúncios das cervejas Brahma e Skoll? Ou é a estrutura dos anúncios que apresenta categorias nas quais experimentamos, enquanto efeito, o clima descontraído? Como já sabemos, Williamson é mais favorável à solução estruturalista, principalmente em sua aproximação ao pensamento althusseriano (ver mais adiante).

Já sabemos que, para extrair o referente emocional dos anúncios, basta consumir os produtos anunciados. Entretanto, o que os anúncios jamais explicitam é a necessidade de dinheiro: o clima descontraído entre amigos torna-se realmente possível quando pagamos uma rodada de Skoll para todos eles. Este é o quatro e último estágio do processo de transferência realizado pela publicidade. Para Williamson, o produto anunciado

providencia uma moeda (currency) intermediária entre dinheiro verdadeiro e uma emoção, porque ele tem valor em ambos os casos: por um lado, como preço monetário genuíno; por outro, como valor enquanto signo, representando ou substituindo o sentimento de felicidade ou qualquer outro (...). [Os anúncios] geram uma conexão entre um produto e um segundo "produto", amor, felicidade, etc., que se pode comprar. "Dinheiro não pode comprar amor" - mas creme hidratante pode (e dinheiro pode comprar creme hidratante) (WILLIAMSON, 2002, p.38; grifo da autora).

O dinheiro é o elemento implícito, porém fundamental, nas cadeias conotativas forjadas pelos anúncios: o dinheiro que compra o creme hidratante que deixa minha pele suave que me torna bonita que me garante admiração dos homens que... Ao explorar sistemas

Comun. \& Inf., Goiânia, GO, v. 18, n. 1, p. 37-54, jan./jun. 2015 
de referência diversos, a publicidade possibilita que suas diferenças também entrem no mercado, que elas também recebam valor de troca, que enfim se possa perguntar, sem qualquer resquício de humanismo burguês, "quanto custa o amor?" - os aristocratas já calculavam o preço do amor sem se apoiarem em outras moedas como a publicidade.

Depois de explicar o processo de transferência realizado pela publicidade, Williamson aborda aqueles que ativam este processo, ou seja, os consumidores. Para tanto, ela se utiliza de várias formulações oriundas da teoria estruturalista, como interpelação (Althusser), totemismo (Lévi-Strauss) e fase do espelho (Lacan). A respeito da interpelação, Williamson compreende que o consumidor de anúncios "não é um simples receptor, mas um criador de sentido; contudo, o receptor somente é um criador de sentido porque ele é chamado para fazer isso" (WILLIAMSON, 2002, p.41; grifo da autora). Quem nos chama é uma voz que jamais conseguimos identificar nos anúncios, porque "a publicidade não tem 'sujeito"' (WILLIAMSON, 2002, p.14):

Obviamente, as pessoas inventam e produzem anúncios, mas desconsiderando que elas são desconhecidas e sem rostos, o anúncio, em todos os casos, não é reivindicado por elas, não é a fala delas. Então há um espaço, uma lacuna onde o falante deveria estar; e uma das características peculiares da publicidade é que nós somos atraídos para preencher esta lacuna, tornando-se assim tanto ouvinte quanto falante, sujeito e objeto (WILLIAMSON, 2002, p.14).

Quem pede para o consumidor "pensar diferente" (Apple)? Ou para "obedecer sua sede" (Sprite)? A voz impessoal da publicidade é o espaço onde ocorre aquilo que Althusser define como interpelação da ideologia. Para Althusser, a ideologia interpela os indivíduos enquanto sujeitos, ou seja, os indivíduos são livremente sujeitados à ideologia: "Os sujeitos se constituem pela sua sujeição" (ALTHUSSER, 1983, p.104; grifo do autor). Neste sentido, "a existência da ideologia e a interpelação dos indivíduos enquanto sujeitos são uma única e mesma coisa" (ALTHUSSER, 1983, p.97). Ou seja, ao falar como sujeito sobre a ideologia, o indivíduo é falado por ela, torna-se seu objeto, sua existência. Para significar um anúncio, preciso aceitar livremente sua mensagem. Contudo, quando aceito a mensagem do anúncio, não estou mais significando o anúncio, e sim o anúncio está se significando por mim e para mim, dizendo por mim para "pensar diferente", "obedecer minha sede", etc. A voz impessoal do slogan torna-se a voz do sujeito interpelado pela ideologia do anúncio, falando para si mesmo o que deve fazer.

Considerando o processo de interpelação da publicidade, Williamson reconhece quatro etapas simultâneas, ordenadas somente para fins de análise: “ $\left(1^{\mathrm{a}}\right)$ como nós criamos o

Comun. \& Inf., Goiânia, GO, v. 18, n. 1, p. 37-54, jan./jun. 2015 
sentido de um produto em um anúncio; $\left(2^{\mathrm{a}}\right)$ como nós tomamos este sentido do produto; $\left(3^{\mathrm{a}}\right)$ como nós somos criados pelo anúncio; e $\left(4^{\mathrm{a}}\right)$ como nós criamos nós mesmos no anúncio" (WILLIAMSON, 2002, p.41; grifo da autora). A respeito da primeira etapa, Williamson (2002, p.44) afirma que a transferência de valor entre o produto e os sistemas de referência não encontra-se realizada nos anúncios, cabendo ao consumidor realizar esta transferência. Neste momento, o consumidor está livremente se sujeitando à ideologia da publicidade, pois "quando os anúncios colocam duas coisas lado a lado coexistindo, nós não questionamos o sentido disto" (WILLIAMSON, 2002, p.29). Ou seja, a forma da publicidade - "por exemplo, a justaposição ilógica entre um rosto e um perfume" (WILLIAMSON, 2002, p.29) - mostrase ideológica quando o indivíduo está livremente se sujeitando a equivaler o produto e os sistemas de referência.

Sobre a segunda etapa, Williamson explora o conceito de totemismo como abordado por Lévi-Strauss em O pensamento selvagem (1962). Entretanto, ao invés de estabelecer uma relação entre natureza e cultura, como ocorre no totemismo tribal, a publicidade estabelece uma relação entre produtos e pessoas (WILLIAMSON, 2002, p.46-47). Isto se evidencia desde o momento inicial, ainda no plano de marketing, quando se procura definir o públicoalvo ou o posicionamento de determinado produto em relação à concorrência. Neste ponto, o enfoque de Williamson se assemelha ao de Rocha em Magia e Capitalismo (1984), principalmente quando este afirma que, "assim como o 'operador totêmico', a publicidade promove a aliança pela complementaridade que estabelece entre produtos e pessoas" (ROCHA, 1990, p.107). Considerando esta semelhança, é curioso não encontrar referência ao trabalho de Williamson em Magia e Capitalismo, clássico brasileiro de antropologia do consumo. Sem desconsiderar o simples desconhecimento da obra, talvez a principal razão desta ausência seja a abordagem privilegiada por cada autor: a semiologia por Williamson e a antropologia por Rocha. Talvez por esta razão também que Rocha utiliza de modo mais rigoroso e criativo o conceito de totemismo: ao invés de negar a relação entre natureza e cultura, como faz Williamson, Rocha prefere "concordar que ao menos uma forma pela qual a categoria de 'natureza' se traduz entre nós é no domínio da 'produção"', ou seja, a produção é o "outro", o "não-humano", o "indiferenciado", o "anônimo", enfim, "o lugar da alienação do homem frente ao seu trabalho" (ROCHA, 1990, p.106).

Assim, a questão do totemismo poderia ser vista no "pensamento burguês" como uma transcendência entre "natureza" e "cultura" traduzidos em "produção" e "consumo". Estas são, nesse sentido, as categorias fundamentais em oposição. Entre elas, organizando a diferença e a complementaridade, fica o sistema publicitário (ROCHA, 1990, p.106).

Comun. \& Inf., Goiânia, GO, v. 18, n. 1, p. 37-54, jan./jun. 2015 
Através do sistema publicitário, a indiferença "natural" e "não-humana" dos produtos é revestida de valores próprios, "culturais" e "humanos": "Ao nomear os produtos, ao identificá-los e climatizá-los, a publicidade os diferencia e os traz para o nosso mundo. A publicidade individualiza cada produto como o passo fundamental para torná-lo 'humano"' (ROCHA, 1990, p.108). Enquanto Williamson justifica a publicidade a partir da indiferença inerente à produção em série, Rocha vai além, justificando-a também a partir de sua dimensão antropológica: a necessidade de "humanização" dos produtos. Contudo, isto não o afasta de uma crítica da publicidade, como ocorre com vários autores ligados à antropologia do consumo - este é o caso, por exemplo, de Grant McCracken, para quem os bens de consumo "não são prisões, mas instrumentos para a personalidade" (MCCRACKEN, 2012, p.14). Para Rocha, ao atribuir identidade aos produtos, a publicidade os prepara "para uma existência não mais marcada pelas relações de produção" (ROCHA, 1990, p.62), ou seja, pelas relações entre aqueles que, detentores dos meios de produção, compram a força de trabalho daqueles que nada possuem. Reencontramos em palavras semelhantes a seguinte crítica de Williamson:

Uma razão para meu uso da palavra "totemismo" é que ela descreve uma formação particular de grupos que não pode ser confundida com os grupos de diferença de classe. Os anúncios obscurecem e evitam os verdadeiros problemas da sociedade, aqueles relacionados ao trabalho: empregos, salários e quem trabalha para quem (WILLIAMSON, 2002, p.47).

Como verdadeira ideologia, a publicidade oculta aquilo que a crítica marxista reconhece como reprodução da força de trabalho, onde o salário representa o mínimo histórico e biológico indispensável para que trabalhadores continuem trabalhando (ALTHUSSER, 1983, p.56-57). Isto somente é possível porque "nós, isoladamente, nos tornamos a 'identidade totêmica' que o produto deve possuir para 'significar'" (WILLIAMSON, 2002, p.51; grifo do autor). Sendo assim, esquecemos o papel de produtores explorados para abraçar o de consumidores felizes que os anúncios nos oferecem. Esta é a terceira etapa do processo de interpelação da publicidade, relacionada à sujeição do indivíduo: "você é significado [pela publicidade] pelo simples fato de você dar significado a ela" (WILLIAMSON, 2002, p.55).

$\mathrm{Na}$ última etapa, a publicidade torna-se o espelho onde o indivíduo sujeitado se enxerga a si mesmo; entretanto, ele se enxerga tal como uma criança que percebe o reflexo não como representação, mas como extensão de si. Williamson se vale aqui de "O estágio do espelho como formador da função do eu" (1949), de Jacques Lacan, resumindo seus principais conceitos do seguinte modo: 
A relação da criança com sua imagem especular envolve duas percepções contraditórias. Uma é que ela e sua imagem são o mesmo; no nível do Imaginário, a barreira do espelho é quebrada e há um fluxo de identificação entre o eu da criança e sua representação, a imagem do eu. Esta unidade imaginária é o ideal do ego. Paradoxalmente, contudo, para a imagem representar o eu "unificado", ela deve ser separada do eu; isto porque um signo deve significar alguma coisa, e para a imagem "significar" a criança, inevitavelmente ela não pode ser ela. Então duas áreas são produzidas: aquela onde a igualdade (sameness) existe, o Imaginário; e aquela onde a diferença existe, o Simbólico (WILLIAMSON, 2002, p.62; grifos da autora).

Contudo, na publicidade, “o 'Simbólico', a diferença que torna a significação possível, é sempre disfarçado nos anúncios pela igualdade imaginária. Na troca do presente pelo ausente, do signo pelo sentido, os anúncios pressupõem uma identidade entre os dois que eles são o mesmo" (WILLIAMSON, 2002, p.75; grifo da autora). Portanto, em seu processo de interpelação, a publicidade disfarça a diferença, porém não se trata daquela diferença corriqueira que se experimenta quando se depara com anúncios que exibem corpos identicamente "perfeitos": esta diferença é bem visível, inclusive criticada pela própria publicidade em poucos momentos, como na campanha "Real beleza" da marca Dove. Na verdade, a publicidade oculta a diferença simbólica, geradora de sentido, distante da idealização. Mesmo reconhecendo os corpos dos anúncios como não sendo os seus, os consumidores os desejam e os idealizam, enfim, eles querem ser aqueles corpos - fazendo isto, a publicidade impede de se enxergar a beleza em outros sentidos, de modo diferente.

O extenso caminho que percorremos até agora mostra claramente a filiação da autora à corrente estruturalista, principalmente ao pensamento de Althusser, denominado por ela como "uma teoria marxista sofisticada da significação" (WILLIAMSON, 2002, p.40). Curiosamente, no mesmo ano de publicação de DecodingAdvertisements, Edward Thompson, expoente dos Estudos Culturais, criticaria intensamente o marxismo althusseriano em $A$ pobreza da teoria (1978), reclamando, entre outros pontos, sobre a ausência do conceito de experiência no processo de interpelação (THOMPSON, 1981, p.182-183). Por outro lado, Hall compreende a avaliação de Thompson como parcial, incapaz de reconhecer que "avanços reais estavam sendo alcançados pela obra de Althusser" (HALL, 2003c, p.169), como é o caso da problematização do conceito monolítico de "modo de produção". Na verdade, para Hall, a grande lacuna do marxismo althusseriano verifica-se na forma como o famoso ensaio "Aparelhos ideológicos de Estado" (1970) é dividido em duas partes:

A Parte I trata da ideologia e da reprodução das relações sociais de produção. A Parte II estuda a constituição dos sujeitos e como as ideologias nos interpelam no domínio do Imaginário. Ao tratar esses dois aspectos em dois compartimentos distintos, ocorre um deslocamento fatal. O que em

Comun. \& Inf., Goiânia, GO, v. 18, n. 1, p. 37-54, jan./jun. 2015 
princípio foi concebido como um elemento crítico dentro da teoria geral da ideologia - a teoria do sujeito - passa a ser, metonimicamente, o todo da própria teoria (HALL, 2003c, p.177-178).

Althusser não consegue, portanto, unir os dois compartimentos, mostrar como o processo de interpelação contribui para a reprodução das relações sociais de produção. Esta também é a fraqueza dos Estudos Culturais, cuja evolução histórica favorece o pólo da subjetividade, ao invés do pólo da reprodução social. Igualmente é a fraqueza de DecodingAdvertisementsque, ao privilegiar a Parte II do ensaio de Althusser, esquece de ancorar sua análise ao processo publicitário de produção e consumo.

\section{O PARADIGMA CULTURALISTA}

Algumas críticas a DecodingAdvertisements decorrem de seu apego excessivo ao paradigma estruturalista, especialmente ao conceito de interpelação. Sobre este conceito, Hall compreende que "os mecanismos universais de interpelação podem fornecer as condições gerais necessárias à linguagem”, porém é "mera especulação afirmar que eles fornecem as condições concretas e suficientes à enunciação de ideologias historicamente específicas e diferenciadas" (HALL, 2003c, p.185). Ou seja, a interpelação é um conceito geral, abstrato, incapaz de abarcar demandas socialmente e historicamente situadas, como é o caso da publicidade em relação ao seu público diversificado. Não por acaso, os críticos de Williamson evocam justamente essa ausência em sua obra. Para Wells, "a falta de direcionamento adequado ao leitor [de anúncios] como sujeito ativo, individualizado, localizado socialmente e culturalmente, é uma das fraquezas centrais do estudo" (WELLS, 2004, p.173). Do mesmo modo, Sinclair afirma que Williamson desconsidera "como práticas de marketing se esforçam para atender não apenas qualquer um, mas certos grupos-alvo que são selecionados pelo emprego de técnicas de posicionamento e discursos que se espera que eles possam, em particular, compreender" (SINCLAIR, 1987, p.51). Em ambas as críticas, percebe-se como a generalidade da interpelação encobre as especificidades do processo publicitário.

Harms e Kellner (1991) avaliam DecodingAdvertisements como uma "contribuição importante para a microanálise da publicidade", influenciando estudos marxistas e feministas posteriores. Contudo, para os autores, análises como a de Williamson frequentemente falham em três pontos: (1) em suas perspectivas históricas; (2) em suas teorizações da publicidade como instituição; e (3) em suas propostas para restringir o crescente poder da publicidade (HARMS; KELLNER, 1991). Na verdade, sobre este último ponto, Williamson entende que a 
publicidade é incontrolável, pois "quaisquer que sejam as restrições que se façam ao seu conteúdo verbal ou às suas 'falsas chamadas', não há como apreender o seu uso de imagens e símbolos" (WILLIAMSON, 2002, p.175). Isto se deve à já observada capacidade de recuperação da publicidade, capaz de reverter ou neutralizar qualquer crítica direcionada a ela.

Como forma de evitar as falhas apontadas acima, Harms e Kellner sugerem que "esse tipo de leitura atenta [close reading] poderia combinar microanálise de textos específicos, métodos de publicidade e seus efeitos na vida cotidiana com macroanálise das funções sociais mais amplas da publicidade" (HARMS; KELLNER, 1991). Isto é exatamente o que Leiss, Kline e Jhally fazem em Social Communication in Advertising, combinando análise semiológica e de conteúdo em um método que "oferece um meio de especificar e mensurar quantitativamente os elementos diferentes que compõem os códigos publicitários quando eles são direcionados a segmentos específicos de audiência" (LEISS; KLINE; JHALLY, 1986, p.175-176). Sendo assim, a microanálise semiológica identifica os elementos dos códigos publicitários que servem como categorias para a macroanálise de conteúdo. Os autores optaram por essa metodologia de "alcance médio" após relacionarem fraquezas a ambos os tipos de análise. Sobre a análise semiológica, referindo-se principalmente ao trabalho de Williamson, os autores citam três fraquezas: (1) a análise semiológica é extremamente dependente da habilidade do analista; (2) ela é incapaz de quantificar resultados e avaliar um grande número de mensagens; e (3) ela não é aplicável com igual sucesso a todos os tipos de anúncios, sendo necessário selecionar aqueles que exemplifiquem os pontos levantados pelo analista (LEISS; KLINE; JHALLY, 1986, p.165).

A importância relativa do paradigma culturalista em DecodingAdvertisements se faz sentir quando os críticos cobram a presença dos apontamentos de Williams. De acordo com Wells, há vários pontos em "Publicidade: o sistema mágico" que poderiam ajudar Williamson a ancorar sua abordagem semiológica, como é o caso da publicidade enquanto sistema mágico que, ao dotar os produtos de qualidade cultural, obscurece o usuário a favor do consumidor (WELLS, 2004, p.173-174). É por isso que, para Williams, nossa sociedade não é suficientemente materialista, pois ela ainda necessita da qualidade cultural dos produtos, ou em outras palavras, o valor de uso não nos basta: “A cerveja nos bastaria, sem a promessa adicional de que, tomando-a, pareceríamos mais viris, mais jovens ou mais sociáveis" (WILLIAMS, 2011a, p.252). Por outro lado, na visão de Sinclair, Williamson aproxima-se algumas vezes da "concepção culturalista de hegemonia, a luta histórica contínua pelo 
significado entre as forças capitalistas dominantes e os grupos sociais subordinados" (SINCLAIR, 1987, p.52), principalmente quando, em suas conclusões, admite as fraquezas do método estruturalista em analisar as necessidades verdadeiras de sujeitos verdadeiros. Contudo, admitir fraquezas não absolve a omissão da autora em relação ao paradigma culturalista: o próprio Sinclair é enfático quando afirma que, em DecodingAdvertisements, "os conceitos estruturais são discutidos de um jeito abstrato, desconectado do modo como anúncios específicos estão localizados historicamente e culturalmente, bem como nas estratégias de marketing" (SINCLAIR, 1987, p.52). Na verdade, se lembrarmos que Williams define hegemonia como "um conjunto de significados e valores que, do modo como são experimentados enquanto práticas, aparecem confirmando-se mutuamente" (WILLIAMS, 2011b, p.53; grifo nosso), podemos entender que a lacuna do conceito de interpelação é a mesma da análise de Williamson: a experiência, ou seja, o modo como o conjunto de significados e valores da publicidade são experimentados por consumidores específicos. Também não é demais lembrar que o sujeito da interpelação "não pode ser confundido com o indivíduo historicamente vivido" (HALL, 2003c, p.177). Bastante elogiado por mostrar como a publicidade funciona, DecodingAdvertisements não consegue mostrar como a publicidade funciona em condições específicas e através de pessoas específicas.

Acompanhando o pensamento de Williams, Williamson poderia compreender a publicidade como estrutura de sentimento. Originalmente proposto para pensar a literatura e outras artes, o conceito de Williams se interessa por "significados e valores tal como são vividos e sentidos ativamente", considerando esses elementos tanto como estrutura quanto como processo:

Estamos então definindo esses elementos como uma "estrutura": como uma série, com relações internas específicas, ao mesmo tempo engrenadas e em tensão. Não obstante, estamos também definindo uma experiência social que está ainda em processo, com frequência ainda não reconhecida como social, mas como privada, idiossincrática, e mesmo isoladora, mas que na análise (e raramente de outro modo) tem suas características emergentes, relacionadoras e dominantes, e na verdade suas hierarquias específicas (WILLIAMS, 1979, p.134; grifo do autor).

Williamson preocupa-se apenas em estabelecer as relações internas da estrutura da publicidade. Desconsidera a publicidade em processo, aquela que ocorre como experiência de produção (estratégia de marketing, criação, etc.) ou de consumo (recepção de anúncios, comportamento de compra, etc.). A publicidade vista como estrutura, mas não vista como processo - esta é a principal crítica a DecodingAdvertisements. 


\section{CONSIDERAÇÕES FINAIS}

$\mathrm{O}$ estudante brasileiro de publicidade provavelmente pouco conhece DecodingAdvertisements, obra que há muito tempo pede uma tradução, principalmente por seus exemplos abundantes de análise (mais de 115 peças publicitárias são analisadas). Talvez o único contato do estudante com as ideias de Williamson tenha ocorrido em A linguagem da propaganda, livro disponível ao público brasileiro desde 1988, cujo último capítulo é dedicado quase inteiramente ao pensamento da autora. Por que essa negligência, principalmente em um momento que tanto se fala em Estudos Culturais? Sem considerar as especificidades do mercado editorial, ainda mais específicas quando se trata de livros técnicos e editoras universitárias, alguns fatores certamente contribuíram para tanto, como a complexidade da obra e sua suposta obsolescência. Isto nos remente à pergunta inicial deste artigo: DecodingAdvertisements é uma obra “datada"? Quando faz esta afirmação, Wells está pensando no conjunto de circunstâncias acadêmicas, políticas e pessoais que tanto facilitaram quanto limitaram a repercussão de DecodingAdvertisements: por um lado, a obra de Williamson aproveita-se do repentino interesse por cultura popular demonstrado por estudantes recém-ingressos no Center for Contemporary Cultural Studies(CCCS); por outro lado, ela concentra-se por demais em debates (anti-)estruturalistas que hoje são "assunto de história acadêmica" (WELLS, 2004, p.167-168). Contudo, a crítica de Wells parece reforçar aquilo que França indica como uma das dificuldades das teorias da comunicação, o modismo: "quadros conceituais, temáticas e vertentes explicativas se sucedem ao longo dos anos, sem alcançar o necessário aprofundamento e maturação" (FRANÇA, 2001, p.50). Não é preciso repassar os caminhos levantados pela pesquisa de Williamson para perceber como muitos encontram-se incompletos, principalmente aqueles que resultaram em críticas: Williamson e outros autores nos mostraram a estrutura da publicidade, agora precisamos avaliá-la enquanto processo. Este é o caminho que, para citar um exemplo, Piedras tenta percorrer em Fluxo publicitário (2009).

No mais recente prefácio de DecodingAdvertisements, publicado em 2002, Williamson se refere à atualidade do marxismo e de seu próprio estudo nos seguintes termos:

Esses conceitos [marxistas] são tão atuais como sempre, e podem nos ajudar a entender o que agora chamamos de globalização e branding - o que uma vez foi chamado de imperialismo econômico e marketing. A moda nas palavras muda, frequentemente mais rápida que o fenômeno que elas se referem: isto quase sempre oferece uma nova forma de enxergar as mesmas coisas. Contudo, isto pode às vezes dar a impressão que o mundo está mudando mais rápido do que realmente parece (WILLIAMSON, 2002, p.7). 
O tempo não para... mas os problemas persistem, mesmo em novas roupagens. A afirmação de Williamson parece ecoar o seguinte apelo de Sartre, deixado aqui como conclusão reflexiva sobre ideias "defasadas": "enquanto o sistema [capitalista] subsiste, produzindo ainda suas mistificações, suas ideias, suas reivindicações, seus homens, aquela filosofia [de Marx], nascida no momento em que o sistema tomou consciência de si mesmo, permanece insuperável” (SARTRE, 2005, p.35).

\section{REFERÊNCIAS}

ALTHUSSER, L. Aparelhos ideológicos de Estado: nota sobre os aparelhos ideológicos de Estado. Rio de Janeiro: Edições Graal, 1983.

BARTHES, R. Mitologias. São Paulo: DIFEL, 1980.

BARTHES, R. A mensagem publicitária. In: A aventura semiológica. Lisboa: Edições 70, 1987.

BAUDRILLARD, J. Simulacros e simulações. Lisboa: Relógiod'Água, 1991.

DYER, G. Advertising as communication. London: Methuen, 1982.

FRANÇA, V. V. O objeto da comunicação/a comunicação como objeto. In: HOHFELDT, A.; MARTINO, L. C.; FRANÇA, V. V. Teorias da comunicação: conceitos, escolas e tendências. Petrópolis: Vozes, 2001.

HALL, S. Estudos Culturais e seu legado teórico. In:HALL, S. Da diáspora: identidades e mediações culturais. Belo Horizonte: Ed. UFMG, 2003. p. 199-218.

HALL, S. Significação, representação, ideologia: Althusser e os debates pós-estruturalistas. In:HALL, S. Da diáspora: identidades e mediações culturais. Belo Horizonte: Ed. UFMG, 2003.

HARMS, J.; KELLNER, D. Toward a Critical Theory of Advertising.Illuminations. [S.1.]. Disponível em: <http://www.uta.edu/huma/illuminations/kell6.htm>. Acessoem: 23 mar. 2014.

LEISS, W.; KLINE, S.; JHALLY, S. Social Communication in Advertising: persons, products and images of well-being. London: Methuen, 1986.

MARX, K. O 18 Brumário de Luís Bonaparte. São Paulo: Martin Claret, 2008.

MATTELART, A.; NEVEU, E. Introdução aos estudos culturais. São Paulo: Parábola Editorial, 2004.

MCCRACKEN, G. Cultura \& Consumo II: mercados, significados e gerenciamento de marcas. Tradução Ana Carolina Balthazar. Rio de Janeiro: MAUAD, 2012.

ROCHA, E. P. G. Magia e capitalismo: um estudo antropológico da publicidade. São Paulo: Brasiliense, 1990.

SANTAELLA, L.; NÖTH, W. Estratégias semióticas da publicidade. São Paulo: Cengage Learning, 2010. 
SARTRE, J.P. A filosofia marxista. In:SARTRE, J. P. Sartre no Brasil: a conferência de Araraquara. São Paulo:UNESP, 2005. p. 27-38.

SINCLAIR, J. Images Incorporated: advertising as industry and ideology. Kent: CroomHelm, 1987. THOMPSON, E. P. Miséria da teoria: ou um planetário de erros. Rio de Janeiro: Zahar, 1981.

VESTERGAARD, T.; SCHRODER, K. A linguagem da propaganda. São Paulo: Martins Fontes, 1988.

WELLS, L. J. W. Decoding Advertisements. In: BARKER, M.; BEEZER, A. (Orgs.). Reading into cultural studies. London: Routledge, 2004.

WILLIAMS, R. Marxismo e literatura. Rio de Janeiro: Zahar, 1979.

WILLIAMS, R. Publicidade: o sistema mágico. In:WILLIAMS, R. Cultura e materialismo. São Paulo: Ed. UNESP, 2011. p. 231-266.

WILLIAMS, R. Base e superestrutura na teoria da cultura marxista. In:WILLIAMS, R.Cultura e materialismo. São Paulo: Ed. UNESP, 2011. p. 43-68.

WILLIAMSON, J. Decoding advertisements: ideology and meaning in advertising. London: Marion Boyars, 2002.

WILLIAMSON, J. Preface to the fourth impression. In:WILLIAMSON, J. Decoding advertisements: ideology and meaning in advertising. London: Marion Boyars, 1992. p. 6-39.

Recebido em:23/08/2014

Aceito em:22/10/2014

Publicado em: 15/06/2015 